\title{
Synthesis of high purity aluminum nitride nanopowder by RF induction thermal plasma
}

\author{
Kyung-In Kim****, Sung-Churl Choi**, Kyu-Sung Han*, Kwang-Taek Hwang* and Jin-Ho Kim*,† \\ *Icheon Branch, Korea Institute of Ceramic Engineering and Technology, Icheon 467-843, Korea \\ **Department of Advanced Materials Science and Engineering, Hanyang University, Seoul 133-791, Korea
}

(Received October 16, 2013)

(Revised November 28, 2013)

(Accepted December 6, 2013)

\begin{abstract}
Aluminum nitride, which has outstanding properties such as high thermal conductivity and electrical resistivity, has been received a great attention as a substrate and packaging material of semiconductor devices. Since aluminum nitride has a high sintering temperature of $2173 \mathrm{~K}$ and its properties depends on the impurity level, it is necessary to synthesize high-purity and nano-sized aluminum nitride powders for the applications. In this research, we synthesized high purity aluminum nitride nanopowders from aluminum using RF induction thermal plasma system. Sheath gas $\left(\mathrm{NH}_{3}\right)$ flow was controlled to establish the synthesis condition of high purity aluminum nitride nanopowders. The obtained aluminum nitride nanopowders were evaluated by XRD, SEM, TEM, BET, FTIR and N-O analysis.
\end{abstract}

Key words Aluminum nitride, RF induction thermal plasma, Nanopowder, Ammonia gas flow

\section{유도결합 열 플라즈마를 이용한 고순도 질화알루미늄 나노 분말 합성}

김경인***, 최성철**, 한규성*, 황광택*, 김진호**

*한국세라믹기술원 이천분원, 이천, 467-843

**한양대학교 신소재공학부, 서울, 133-791

(2013년 10월 16일 접수)

(2013년 11월 28일 심사완료)

(2013년 12월 6일 게재확정)

요 약 질화알루미늄(AlN)은 뛰어난 열적, 전기절연성 특성을 갖고 있어 반도체 기판용 재료나 전자 패키징 재료로 주 목받고 있다. 질화알루미늄은 소결온도가 높고 불순물로 인한 물성저하 때문에 고순도화 및 나노원료화가 필수적이다. 본 연구에서는 RF 유도결합 열플라즈마를 이용하여 알루미늄 분말로부터 고순도의 질화알루미늄 나노분말을 합성하였다. Sheath gas로 사용된 암모니아의 유량 제어를 통해 고순도의 질화알루미늄 나노분말이 합성되는 조건을 확립하고자 하였으 며 합성된 분말은 XRD, SEM, TEM, BET, FTIR, N-O분석을 통해 특성분석을 진행하였다.

\section{1. 서 론}

질화알루미늄(Aluminum nitride, $\mathrm{AlN}$ )은 고열전도 $(320 \mathrm{~W} / \mathrm{mK})$, 우수한 전기절연성 $\left(>10^{13} \Omega \cdot \mathrm{cm}\right)$, 실리콘 과 비슷한 열팽창계수 $\left(4.6 \times 10^{-6} \mathrm{~K}^{-1}\right)$, 높은 밴드갭 에너 지 $(6.2 \mathrm{eV})$, 무독성, 할로겐 플라즈마에 대하여 높은 저 항 특성을 가지고 있어 반도체 기판이나 전자 패키징 재 료로 주목받고 있다[1]. 그러나 질화알루미늄은 높은 소

\footnotetext{
Corresponding author

Tel: +82-31-645-1432

Fax: +82-31-645-1488

E-mail: jino.kim@kicet.re.kr
}

결온도 $(2173 \mathrm{~K})$ 를 갖는 대표적인 난소결성 물질로, 이러 한 질화알루미늄은 입자크기를 작게 하여 비표면적을 증 가시킴으로써 소결온도를 낮출 수 있다. 또한 질화알루 미늄 분말에 불순물이 포함되어 있으면 소결시 결함으로 작용하여 질화알루미늄의 특성을 저하시키기 때문에 이 론값에 유사한 물성을 얻기 위해 고순도의 질화알루미늄 을 합성할 수 있는 공정에 관한 연구가 활발히 진행되고 있다[2-4].

$\mathrm{AlN}$ 분말 합성은 일반적으로 직접질화법(Direct nitridation)[5], 열탄소환원 질화법(Cabothermal reductionnitridation)[6, 7], 고온자전합성법(Self-propagating high temperature synthesis)[8, 9], 기상반응법(Vapor phase 
reaction)[10-12], 열 플라즈마 합성법(Thermal plasma synthesis)[4, 13-18]이 이용되고 있다. 직접질화법은 제 조법이 간단하고 제조비용이 낮지만 괴 형태로 합성되기 때문에 추가적으로 파쇄공정이 필요하므로 불순물이 혼 입될 수 있고 나노입자로 분쇄하기에는 어려움이 있으며, 제조된 분말 표면에 산소함유량이 높다[19]. 열탄소환원 질화법은 입자 크기가 균일한 고순도의 미세입자 제조가 가능하고 반응 온도제어가 용이하나 이를 위해서는 고순 도의 알루미나전구체의 사용이 필수적이며 알루미나의 완전 환원이 어렵고 잔류 탄소의 산화공정이 필요하다. 고온자전합성법은 높은 열효율, 빠른 합성반응속도, 고순 도 원료합성의 장점을 갖지만 공정변수가 다양하여 공정 이 복잡하고 성형체 용적 용량에 한정되어 대량생산이 어려우며 직접질화법과 같이 파쇄공정이 추가로 필요하 기 때문에 불순물이 혼입되어 순도가 저하되는 단점이 있다. 화학기상반응법은 $100 \mathrm{~nm}$ 이하의 고순도 나노분말 제조가 용이하지만 일반적으로 염화알루미늄 $\left(\mathrm{AlCl}_{3}\right)$ 고체 원료와 암모니아 $\left(\mathrm{NH}_{3}\right)$ 가스를 사용하여 합성되기 때문에 부산물인 염화암모늄 $\left(\mathrm{NH}_{4} \mathrm{Cl}\right)$ 제거공정이 필요하다.

열플라즈마 합성법은 초고온(약 $\left.10^{4} \mathrm{~K}\right)$ 의 플라즈마 온 도에 의해 합성 반응속도 $(10 \mathrm{~ms})$ 가 매우 짧고 뛰어난 냉 각 속도 $\left(>10^{6} \mathrm{~K} / \mathrm{s}\right)$ 에 의해 균일한 입도의 합성물을 얻을 수 있는 특징이 있다. 또한 고상, 액상, 기상의 다양한 출발원료의 사용이 가능하고 원료의 축방향 주입이 가능 한 특징을 갖고 있다. 대표적인 열플라즈마 토치는 직류 아크 플라즈마(DC arc plasma)와 유도결합플라즈마 (Induction plasma)로 구분된다. 직류 아크 플라즈마 토 치는 텅스텐 음극봉과 동 양극 노즐 간의 직류 아크 방 전을 이용하여 플라즈마를 형성한다. 이때 내부의 텅스 텐 전극이 플라즈마에 노출되어 있어서 전극이 침식되어 장비 내부가 오염되거나, 합성된 물질에 불순물이 존재 할 가능성이 있다. 반면, 유도결합 플라즈마 토치는 석영 관 외부에 감겨있는 유도코일에 전류를 흘려주면 전류의 영향으로 석영관 내부에 자기장이 발생되고, 이 자기장 에 의해 플라즈마가 형성된다. 유도코일은 외부에 설치 되어 있어서 플라즈마에 노출되지 않기 때문에 반응환경 이나 합성물에 불순물이 존재할 가능성이 낮다. 또한 직 류 아크 플라즈마에 비해 유도결합 플라즈마는 플라즈마 부피가 커서 반응물이 플라즈마 내에서 체류하는 시간이 직류 아크 플라즈마의 경우 $1 \mathrm{~ms}$ 미만인 반면에 유도결 합 플라즈마는 최대 $500 \mathrm{~ms}$ 로 길기 때문에 원료를 완전 히 반응시키기에 적합하여 생산성이 뛰어난 장점이 있다 [20-22].

본 연구에서는 이러한 유도결합 플라즈마를 이용하여 고순도의 질화알루미늄 나노분말을 합성하였다. 알루미 늄 분말을 출발원료로 사용하였고 암모니아 가스를 사용 하여 플라즈마 영역에서 질소와 수소로 해리시켜 질소분
위기를 제어하여 질화알루미늄 나노분말을 합성하였다. 암모니아 가스의 유량 제어를 통하여 플라즈마 영역의 질소 농도와 플라즈마 온도를 조절하여 미반응 알루미늄 이 존재하지 않는 가장 적합한 고순도 질화알루미늄 합 성 조건을 확립하고자 하였으며 합성된 질화알루미늄 분 말의 결정구조, 순도분석 및 미세구조를 분석하였다.

\section{2. 실험방법}

\section{1. 화학조성 평형 계산}

온도에 따른 $\mathrm{AlN}$ 합성반응의 결과와 합성과정을 이해 하기 위해 상온에서 $4000 \mathrm{~K}$ 까지 알루미늄과 암모니아의 $1: 1$ 비율 일 때, 화학조성 평형계산을 수행하였다. 평형 조성은 Factsage 6.2[23]를 사용하여 계산하였다.

2.2. 유도결합 플라즈마 장치 및 고순도 질화알루미늄 나노분말 합성 방법

본 연구에서 사용한 유도결합 플라즈마 장치(TDU-30, Tekna Co., Canada)의 모식도는 Fig. 1에 나타내었다. 유도결합 플라즈마 토치(PL-35 Tekna's Induction plasma torch)를 장착하였으며 반응부(Reactor), 사이클론(Cyclone) 그리고 필터부(Filter)로 구성되어 있다. 유도결합 플라즈 마 토치를 이용하여 $18 \mathrm{~kW}$ 의 출력으로 플라즈마를 형성 하였고 반응부의 압력은 $9 \mathrm{psi}$ 로 고정하였다. Central gas 는 플라즈마를 형성하는 가스로 아르곤(Ar, $99.999 \%$ )가 스를 사용하였고 토치부의 유도코일 영역으로 분사된다. 분사된 플라즈마 가스는 유도코일 영역에 형성된 자기장 에 의해 이온화되어 고온의 플라즈마 $\left(>10^{4} \mathrm{~K}\right)$ 가 형성된 다. Sheath gas는 고온의 열 플라즈마로부터 토치 내벽 을 보호하고 반응부의 분위기를 제어하는 반응가스의 역 할을 한다. Sheath gas로는 암모니아 $\left(\mathrm{NH}_{3}, 98 \%\right)$ 가스

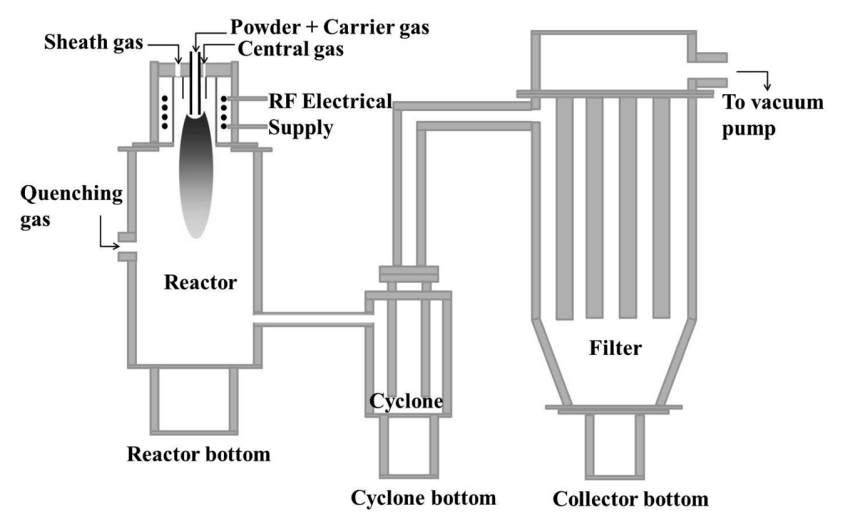

Fig. 1. Schematic diagram of RF induction thermal plasma instrument. 
Table 1

Experimental conditions of AlN synthesis using RF induction thermal plasma

\begin{tabular}{ll}
\hline Precursor & $\mathrm{Al}$ (Aluminum) \\
\hline Plasma power & $18 \mathrm{~kW}$ \\
Central gas $(\mathrm{Ar})$ & $20 \mathrm{slpm}$ \\
Sheath gas $\left(\mathrm{Ar}: \mathrm{NH}_{3}\right)$ & $10 \mathrm{slpm}: 60,80,100 \mathrm{slpm}$ \\
Reactor pressure & $9 \mathrm{psi}$ \\
Feeding rate & $0.171 \mathrm{~g} / \mathrm{min}$ \\
Feeder pressure $(\mathrm{Ar})$ & $0 \mathrm{psi}$ \\
\hline
\end{tabular}

를 사용하였으며, 암모니아 가스 유량을 $60,80,100$ slpm으로 제어하여 반응부의 질소농도를 조절하였다. Quenching gas는 반응물을 초급냉 $\left(>10^{6} \mathrm{~K} / \mathrm{s}\right)$ 의 속도로 결정성장을 억제시켜 입도가 균일한 나노분말 합성이 가 능하게 한다. 질화알루미늄 분말 합성은 $3 \sim 8 \mu \mathrm{m}$ 크기의 구상 알루미늄 $(\mathrm{Al}, 99.8 \%)$ 분말을 출발원료로 사용하였 고, 분말이송에 사용되는 Carrier gas로는 아르곤(Ar, $99.999 \%$ )가스를 사용하여 플라즈마 영역에 축방향으로 주입하여 질화알루미늄 나노분말을 합성하였다. 실험조 건을 Table 1 에 나타내었다.

\section{3. 질화알루미늄 나노 분말 특성 분석방법}

유도결합 플라즈마를 이용하여 합성된 질화알루미늄 나노 분말의 결정상 및 성분분석은 X-ray diffractometer (XRD, D/MAX2500VL/PC, Rigaku)와 Energy dispersive spectrometer(EDS, JEOL, Japan)를 이용하여 수행하였 다. 형상 및 미세구조의 관찰은 Field emission scanning electron microscope(FE-SEM, JSM-7001F, JEOL, Japan) 과 High resolution transmission electron microscope (HR-TEM, JEM4010, JEOL, Japan)을 이용하였다. 질화 알루미늄 나노 분말의 결합구조는 Fourier transform infrared spectrometer(FTIR, Nicolet 6700, Thermo scientific)를 통해 분석되었고 비표면적 측정을 위해 Brunauer emmett teller(BET, Belssorp II mini, BEL, Japan)분석을 수행하였으며, 합성된 입자 표면의 산소 농 도 측정은 Oxygen/Nitrogen analyzer(ON-900, ELTRA) 를 사용하였다.

\section{3. 결과 및 고찰}

Fig. 2의 온도에 따른 화학조성 평형계산 결과에 따르 면 약 $2350 \mathrm{~K}$ 이상에서 알루미늄 기체와 암모니아 가스 가 해리되어 질소와 수소 기체가 형성되기 시작한다. 질 화알루미늄 입자합성은 약 2350 2600 K의 범위에서 알 루미늄 기체와 질소 기체가 반응하여 핵생성과 결정성장

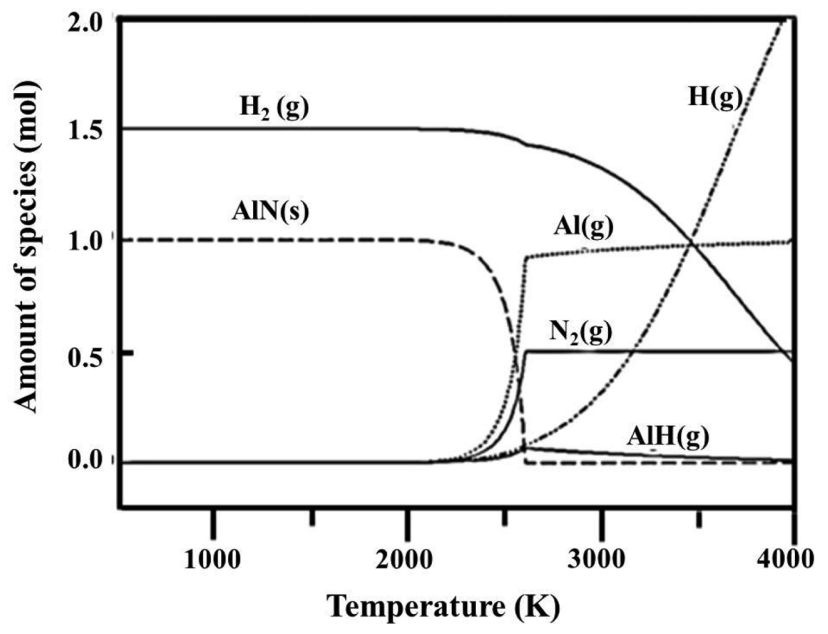

Fig. 2. Chemical equilibrium compositions calculated in $\mathrm{Al}: \mathrm{NH}_{3}$ $(1: 1)$ system as a function of temperature (at $1 \mathrm{~atm}$ ).

이 이루어지며 약 $2350 \mathrm{~K}$ 미만에서는 반응이 이루어지 지 않는다. 플라즈마를 이용한 합성법은 합성물의 반응 시간이 매우 짧기 때문에 합성된 분말은 수 $\mathrm{nm}$ 크기를 가지며 질화알루미늄 입자 합성을 위해서는 플라즈마가 2350 2600 K의 온도분포를 넓게 유지하여야 한다[4]. 유 도결합 플라즈마는 부피가 크고 온도 분포가 좁기 때문 에 질화알루미늄 합성온도 분포를 넓게 유지할 수 있어 질화알루미늄 나노분말 합성에 적합할 것으로 예상된다.

질화알루미늄 합성과정은 고온의 플라즈마 영역 내로 주입된 알루미늄 분말이 융해, 기화, 이온화되며 해리된 암모니아 가스의 질소원자와 반응하여 핵생성 및 결정성 장이 이루어진다. 이 때, 플라즈마 외부의 낮은 온도영역 으로 자유 낙하를 통해 결정성장을 억제시켜 질화알루미 늄 나노 분말이 형성된다. 합성된 분말은 반응부, 사이클 론, 필터부에 각각 포집되며 반응부와 사이클론에는 대

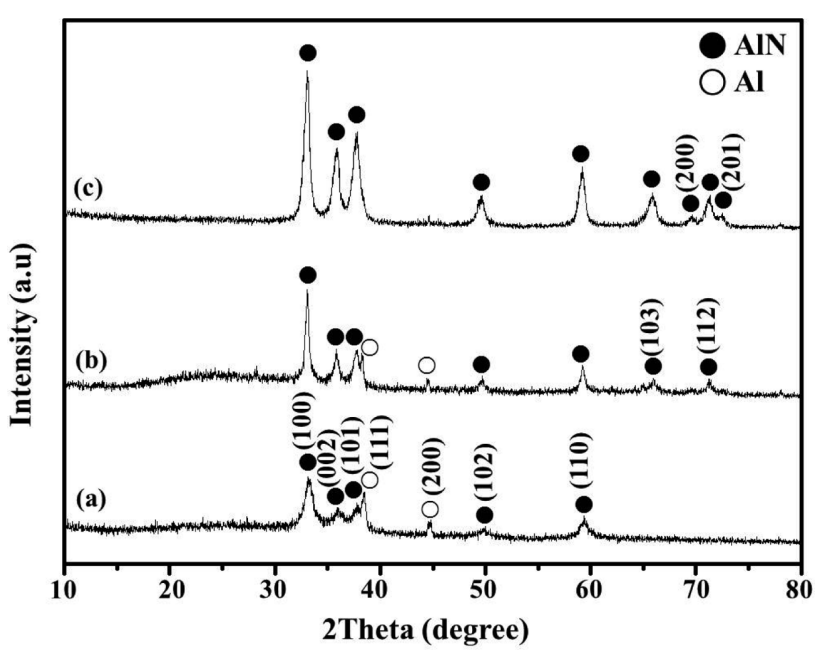

Fig. 3. XRD patterns of synthesized AlN nanopowders with the sheath gas $\left(\mathrm{NH}_{3}\right)$ flow rate of (a) 60 slpm, (b) $80 \mathrm{slpm}$, (c) $100 \mathrm{slpm}$. 
부분 미반응된 알루미늄이 포집되며 필터부로 갈수록 질 화알루미늄 함량이 높기 때문에 본 연구에서는 필터부에 합성된 분말을 포집하여 분석하였다.

암모니아 유량 증가에 따른 질화알루미늄 분말의 $\mathrm{XRD}$ 분석 결과를 $\mathrm{Fig} .3$ 에 나타내었다. XRD 분석결과 Fig. 3(a)의 암모니아 가스 유량을 $60 \mathrm{slpm}$ 으로 제어했을 때에는 $33.0^{\circ}, 35.9^{\circ}, 37.8^{\circ}, 49.6^{\circ}, 59.2^{\circ}$ 에서 hexagonal 결정 구조를 갖는 질화알루미늄의 (100), (002), (101), (102), (110)면의 회절패턴과 $38.3^{\circ}, 44.5^{\circ}$ 에서 알루미늄 의 (111), (200)면의 회절패턴이 함께 관찰되었다. 그러 나 Fig. 3(b)의 암모니아 가스의 유량을 증가시켜 80 slpm으로 제어했을 때에는 질화알루미늄에 해당하는 피 크의 회절강도는 증가하였으며 $65.9^{\circ}, 71.2^{\circ}$ 에서 (103), (112)면의 회절패턴이 추가로 관찰되어 질화알루미늄의 결정성 및 수율이 증가한 것을 확인하였다. 그리고 Fig. 3(c)에서 알 수 있듯이 암모니아 가스의 유량을 100 $\mathrm{slpm}$ 으로 증가시켰을 경우에는 알루미늄에 해당하는 회 절패턴 없이 hexagonal결정 구조를 갖는 질화알루미늄 의 회절패턴만이 관찰되었다. 이러한 결과는 암모니아 가스 유량이 증가할수록 플라즈마 영역에서 해리되는 암 모니아 가스의 양이 증가하여 기화된 알루미늄 원료와 충분히 반응할 수 있을 만큼 반응부에 높은 질소 농도를 형성했기 때문으로 판단된다.

합성된 질화알루미늄 입자의 형상과 조성을 분석하기 위하여 SEM과 EDS 분석을 수행하였다. Fig. 4는 60, $80,100 \mathrm{slpm}$ 의 암모니아 가스를 사용하여 얻어진 질화 알루미늄 분말의 SEM 사진 및 조성분석 결과이다. 출 발 물질로 사용된 알루미늄 분말 입자는 $3 \sim 8 \mu \mathrm{m}$ 크기를 가지므로 플라즈마 영역 내에서 완전히 기화되지 못한 알루미늄 입자는 수 $\mu \mathrm{m}$ 크기를 가질 것으로 예상되어
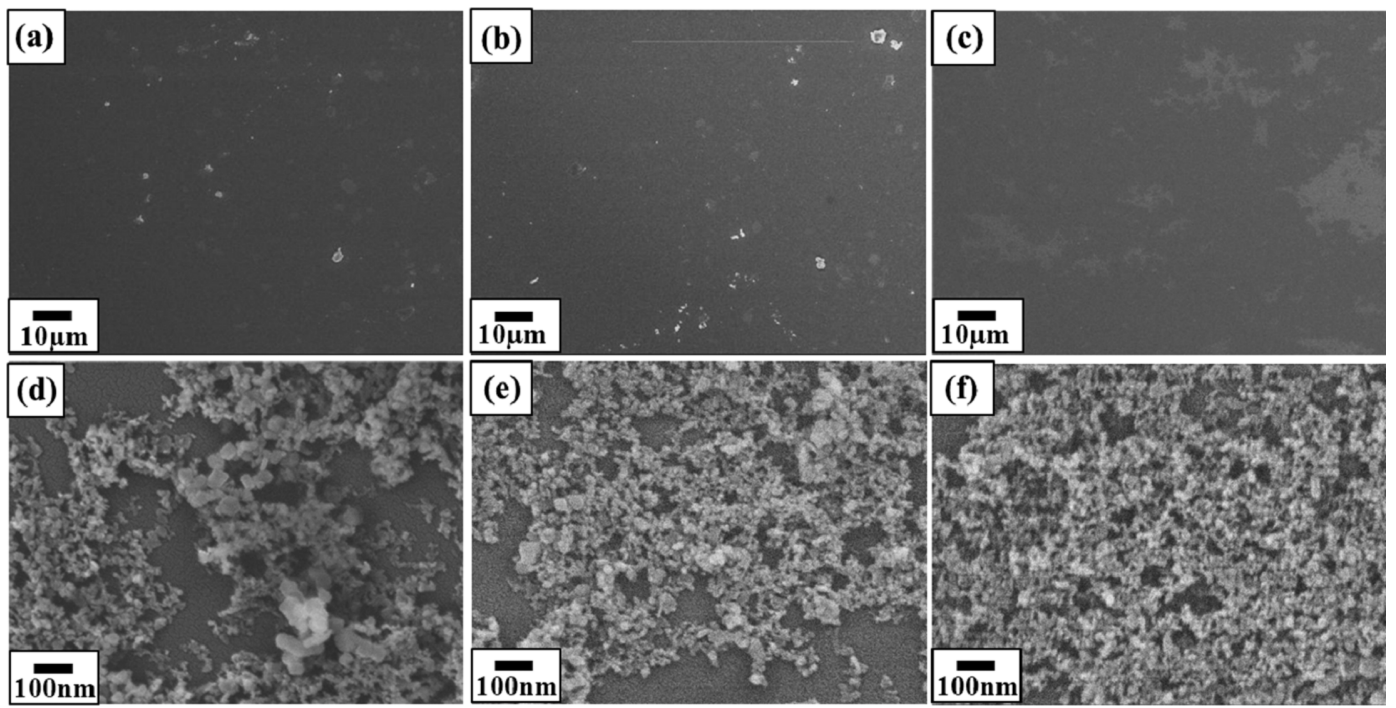

Fig. 4. Low magnification SEM images of the obtained powders with the sheath gas $\left(\mathrm{NH}_{3}\right)$ flow rate of (a) $60 \mathrm{slpm}$, (b) $80 \mathrm{slpm}$, (c) $100 \mathrm{slpm}$. High magnification SEM images of AlN nanoparticles with the sheath gas $\left(\mathrm{NH}_{3}\right)$ flow rate of (d) $60 \mathrm{slpm}$, (e) $80 \mathrm{slpm}$, (f) $100 \mathrm{slpm}$.
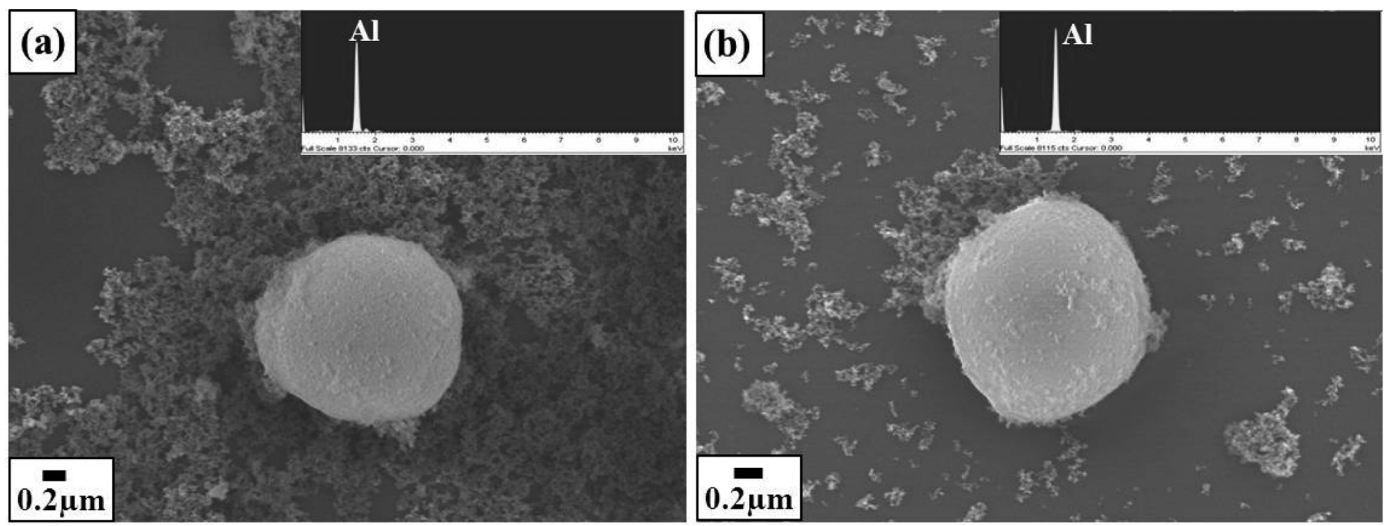

Fig. 5. FE-SEM images and EDS elemental analysis results of unreacted $\mathrm{Al}$ particles under the sheath gas $\left(\mathrm{NH}_{3}\right)$ flow rate of (a) $60 \mathrm{slpm}$ (b) $80 \mathrm{slpm}$. 
Fig. 4(a), (b), (c)에서는 암모니아 가스의 유량이 각각 $60,80,100 \mathrm{slpm}$ 일 때 미반응된 알루미늄 입자의 존재 여부를 저배율의 SEM 사진으로 확인하였다. 암모니아 가스 유량이 각각 $60,80 \mathrm{slpm}$ 일 경우에는 Fig. 4(a), (b)와 같이 약 수 $\mu \mathrm{m}$ 크기의 구형 입자들이 관찰된 반 면에 암모니아 가스 유량이 $100 \mathrm{slpm}$ 일 경우에는 Fig. $3(\mathrm{c})$ 와 같이 수 $\mu \mathrm{m}$ 크기의 구형입자가 관찰되지 않았다. Fig. 4(d), (e), (f)에는 암모니아 가스의 유량이 각각 60, $80,100 \mathrm{slpm}$ 일 때 질화알루미늄으로 판단되는 나노 입 자를 나타내었다. 약 수십 $\mathrm{nm}$ 크기를 보이는 미세 입자 들이 관찰되었으며, 미세 입자는 주로 $50 \sim 100 \mathrm{~nm}$ 크기 의 다각형 입자들과 $20 \mathrm{~nm}$ 이하의 침상 입자들로 구성 되어 있는 것을 관찰하였다. 암모니아 가스 유량을 60 , $80 \mathrm{slpm}$ 으로 제어했을 때 합성된 입자 중에서 수 $\mu \mathrm{m}$ 크
기의 구형 입자를 관찰한 $\mathrm{SEM}$ 사진과 $\mathrm{EDS}$ 분석결과를 각각 Fig. 5(a), (b)에 나타내었다. 입도는 각각 약 1.8 과 $1.6 \mu \mathrm{m}$ 이며 $\mathrm{EDS}$ 분석결과 알루미늄이 확인된 것으로 미루어 보아 이는 출발원료로 사용된 $3 \sim 8 \mu \mathrm{m}$ 크기의 구 형 알루미늄 입자가 플라즈마 영역을 빠르게 통과하였거 나 플라즈마의 중심부를 벗어난 영역을 통과하여 완전하 게 기화되지 못한 것으로 판단된다. $100 \mathrm{~nm}$ 이하의 입 자들은 $\mathrm{SEM}$ 분석을 통한 형상분석에 있어서 한계가 있 기 때문에 $\mathrm{TEM}$ 분석을 진행하였다.

Fig. 6은 60, 80, $100 \mathrm{slpm}$ 의 암모니아 가스를 사용하 여 합성된 질화알루미늄 분말의 TEM 사진과 $\mathrm{EDS}$ 분석 결과이다. 암모니아 가스 유량을 $60 \mathrm{slpm}$ 으로 제어하였 을 때 합성된 분말에서는 Fig. 6(a)의 $30 \sim 100 \mathrm{~nm}$ 크기 를 가지는 구형 입자들과 Fig. 6(b)의 20 50 nm 크기를

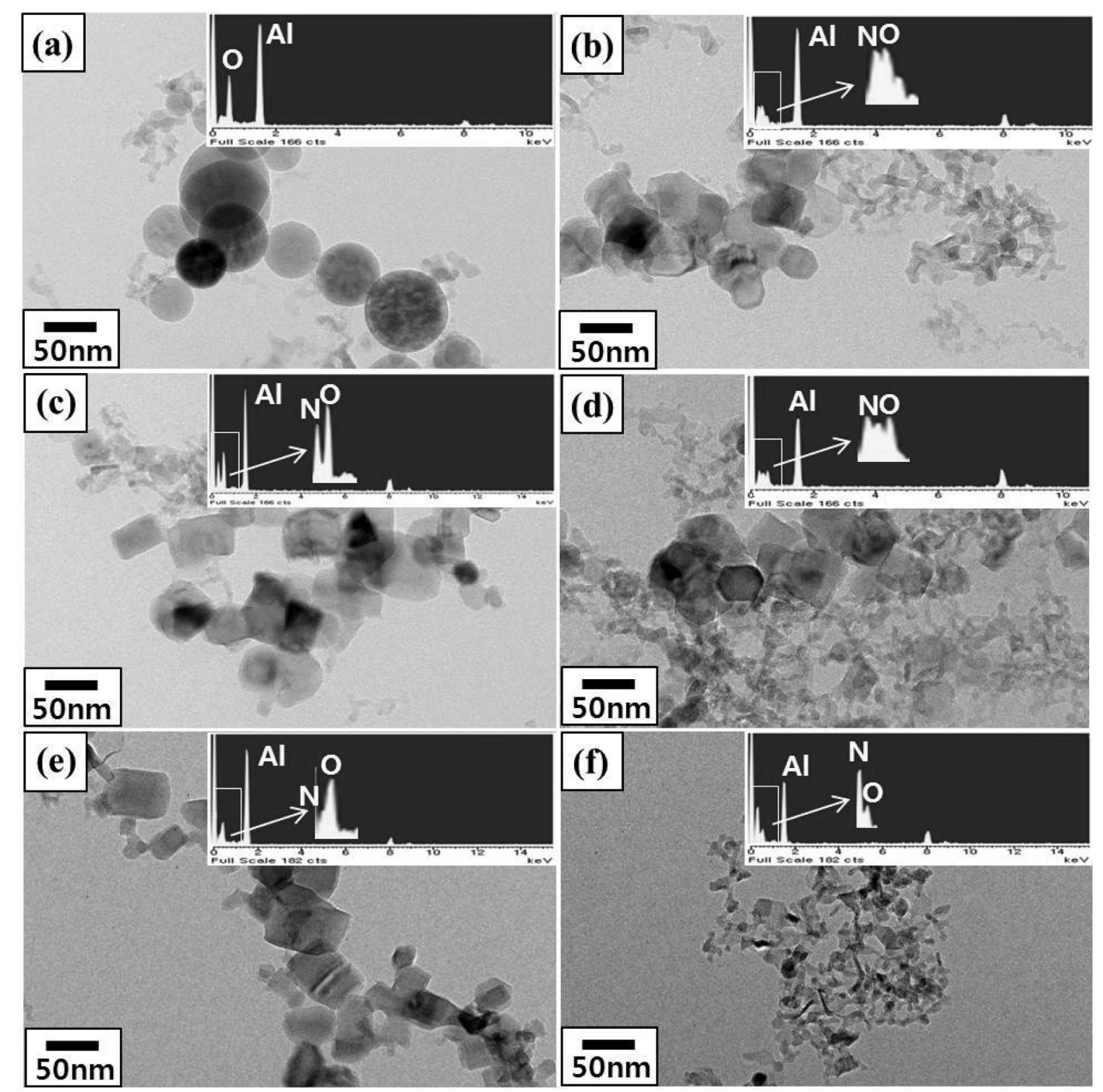

Fig. 6. TEM images and EDS elemental analysis of the obtained powders with the different sheath gas $\left(\mathrm{NH}_{3}\right)$ flow rate: $($ a) $\mathrm{Al}$ nanoparticles $(60 \mathrm{slpm})$ and (b) AlN nanoparticles $(60 \mathrm{slpm})$, (c) AlN polygon-shaped nanoparticles (80 slpm) and (d) AlN needleshaped nanoparticles $(80 \mathrm{slpm})$, (e) AlN polygon-shaped nanoparticles (100 slpm) and (f) AlN needle-shaped nanoparticles (100 slpm). 
가지는 다각형 입자들이 관찰되었다. $\mathrm{EDS}$ 분석을 통해 구형의 입자는 알루미늄과 산소가 포함되어 있고, 다각 형 입자에서는 알루미늄, 질소와 산소가 포함되어 있는 것을 알 수 있었다. 구형의 알루미늄 입자의 경우는 기 존의 플라즈마를 이용한 알루미늄 나노 분말 합성에서 관찰되는 입자형상과 일치하는 것으로 미루어 보아 반응 중 플라즈마 내의 질소농도가 부족하여 일부의 기화된 알루미늄이 질소와 반응하지 못하고 $30 \sim 100 \mathrm{~nm}$ 크기의 구형입자로 합성된 것으로 판단된다[24]. 반면, 다각형의 질화알루미늄 입자들은 $\mathrm{EDS}$ 분석 결과 질화알루미늄으 로 판단되며 이 결과는 앞서 Fig. 3(a)의 XRD 분석 결 과의 질화알루미늄과 알루미늄 상이 공존하는 결과와 일 치한다. 암모니아 가스 유량을 $80 \mathrm{slpm}$ (Fig. 6(c), (d))으 로 제어하였을 때 합성된 분말에서는 $10 ~ 50 \mathrm{~nm}$ 크기의 다각형과 침상 입자들이 관찰되었고 구형의 알루미늄 입 자는 관찰되지 않았으며 $\mathrm{EDS}$ 분석 결과 다각형과 침상 입자들에서는 알루미늄과 질소 그리고 산소가 관찰되었 다. 암모니아 가스 유량을 $100 \mathrm{slpm}$ (Fig. 6(e), (f))으로 제어하였을 때 합성된 분말에서는 Fig. 6(c), (d)과 동일 한 다각형과 침상 입자들이 관찰되었으며, 다각형과 침 상의 입자들의 $\mathrm{EDS}$ 분석 결과에서도 동일 원소가 관찰 되었다. 이러한 결과는 플라즈마 영역에서 구형의 알루 미늄 입자가 질소와 반응하여 hexagonal상의 다각형의 입자로 합성되고 입자 표면의 알루미늄 크러스트가 질소 와 반응하여 사슬형태로 결합되거나 침상의 형태로 결정 성장이 이루어지는 것으로 판단된다[16].

암모니아 가스 유량을 $100 \mathrm{slpm}$ 으로 제어하였을 때 합성된 질화알루미늄 나노분말의 비표면적을 $\mathrm{BET}$ 분석 을 통하여 측정하였다. 측정 결과 비표면적은 $126.18 \mathrm{~m}^{2} /$ $\mathrm{g}$ 으로 측정되었으며, 측정된 비표면적 값을 이용하여 평 균입자 크기를 (1)의 식을 이용하여 계산하였다[25].

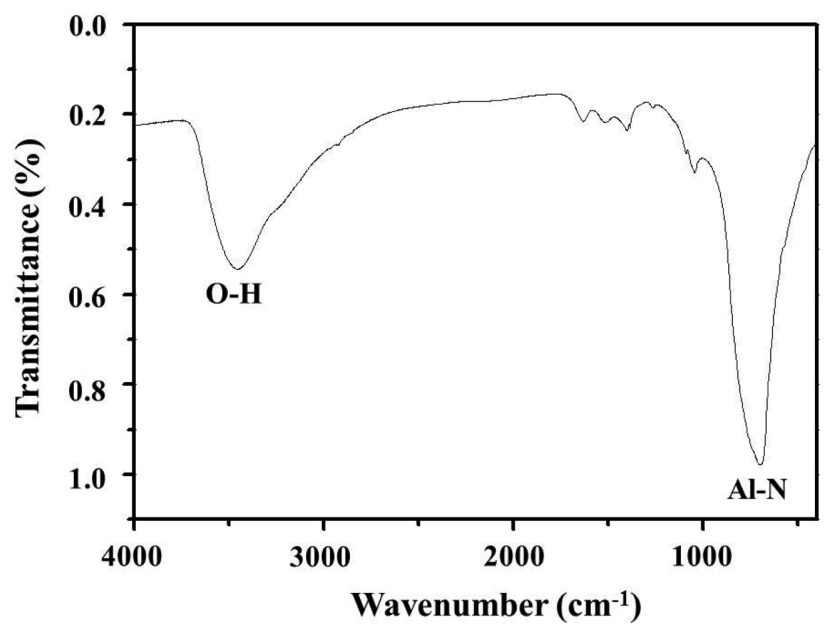

Fig. 7. FTIR spectra of AlN nanopowders synthesized under the sheath gas $\left(\mathrm{NH}_{3}\right)$ flow rate of 100 slpm.

$$
d=6 /\left(\rho \cdot S_{\text {BET }}\right)
$$

식 (1)의 $\mathrm{AlN}$ 의 이론 밀도 $(\rho)$ 는 $3.26 \mathrm{~g} / \mathrm{cm}^{3}, \mathrm{~S}_{\mathrm{BET}}$ 는 $\mathrm{BET}$ 법을 이용해 측정된 비표면적 값을 이용하여 평균 입 자크기 $(\mathrm{d})$ 를 계산한 결과 $14.6 \mathrm{~nm}$ 로 계산되었으며, 이러 한 결과는 TEM 분석에서 확인된 입자 크기와 일치한다.

Fig. 7은 암모니아 가스 유량을 $100 \mathrm{slpm}$ 으로 제어하 였을 때 합성된 분말을 투과모드로 설정하여 FTIR 분석 을 진행한 결과이다. FTIR 분석 결과 $650 \sim 780 \mathrm{~cm}^{-1}$ 영 역에서 약 $1 \%$ 의 투과율을 갖는 $\mathrm{Al}-\mathrm{N}$ 흡수밴드가 관찰 되어 합성된 분말은 높은 질화알루미늄의 함량을 가지는 것으로 판단되며, Fig. 3(c)의 XRD 분석 결과처럼 순수 한 질화알루미늄으로 합성되었음을 확인하였다. 3450 $3442 \mathrm{~cm}^{-1}$ 에서 약 $0.55 \%$ 의 투과율을 갖는 $\mathrm{O}-\mathrm{H}$ 흡수밴 드가 관찰된 것은 질화알루미늄 분말이 공기에 노출되었 을 때 입자 표면에 수분이 흡착된 것으로 판단된다[13, 26]. 질화알루미늄 입자 표면에 수분 흡착 정도를 측정 한 결과 산소 함량이 $9 \mathrm{wt} \%$ 로 측정되었고 이는 기존의 질화알루미늄 나노분말에서 측정되는 산소함량과 유사한 값이다[27].

\section{4. 결 론}

본 연구에서는 RF 유도결합 플라즈마를 이용하여 고 순도 질화알루미늄 나노분말을 합성하였다. 출발원료로 알루미늄 분말을 사용하였으며, 암모니아 가스의 유량을 제어하면서 $\mathrm{XRD}$ 로 결정성과 순도분석을 수행한 결과 암모니아 가스 유량이 $60,80 \mathrm{slpm}$ 일 경우에는 질화알루 미늄과 알루미늄이 공존하였으며 $100 \mathrm{slpm}$ 으로 제어하 였을 때 순수한 질화알루미늄 나노분말을 합성할 수 있 었다. 암모니아 가스 유량이 부족할 경우에는 약 1.6 $1.8 \mu \mathrm{m}$ 크기의 미반응된 구형 알루미늄 입자와 함께 수 십 $\mathrm{nm}$ 크기의 구형 알루미늄 입자가 합성된 것을 확인 하였다. 암모니아의 유량이 증가하여 $100 \mathrm{slpm}$ 에서는 5 $60 \mathrm{~nm}$ 크기의 침상 및 다각형의 질화알루미늄 입자들만 이 관찰되었으며 비표면적을 측정결과 $126.18 \mathrm{~m}^{2} / \mathrm{g}$ 으로 측정되었다. FTIR 분석을 통해 Al-N 흡수 밴드와 O-H 흡수밴드를 확인하였고 표면의 산소 함량은 $9 \mathrm{wt} \%$ 로 측 정되었다.

\section{참 고 문 헌}

[1 ] S.M. Kang, "Morphological study on non-seeded grown AlN single crystals", J. Korean Cryst. Growth Cryst. Technol. 22 (2012) 265.

[2 ] G.A. Slack, R.A. Tanzilli, R.O. Pohl and J.W. Vander- 
sande, "The intrinsic thermal conductivity of AlN", J. Phys. Chem. Solids. 48 (1987) 641.

[ 3 ] A.V. Virkar, T.B. Jackson and R.A. Cutler, "Thermodynamic and kinetic effects of oxygen removal on the thermal conductivity of aluminum nitride", J. Am. Ceram. Soc. 72 (1989) 2031.

[4] H. Ahn, M. Hur and S.H. Hong, "Synthesis of ultrafine powders for aluminum nitride by DC thermal plasma", J. Kor. Inst. Sur. Eng. 29 (1996) 45.

[ 5 ] T. Okada, M. Toriyama and S. Kanzaki, "Direct nitridation of aluminum compacts at low temperature", J. Mat. Sci. 35 (2000) 3105.

[6] S.H. Lee, J.H. Yi, J.H. Kim, Y.N. Ko, Y.J. Hong and Y.C. Kang, "Preparation of nanometer AlN powders by combining spray pyrolysis with carbothermal reduction and nitridation", Ceram. Inter. 37 (2011) 1967.

[ 7 ] T. Yamakawa, J. Tatami, T. Wakihara, K. Komeya and T. Meg, "Synthesis of AlN nanopowder from $\mathrm{c}-\mathrm{Al}_{2} \mathrm{O}_{3}$ by reduction-nitridation in a mixture of $\mathrm{NH}_{3}-\mathrm{C}_{3} \mathrm{H}_{8}$," J. Am. Ceram. Soc. 89 (2006) 171.

[ 8 ] S.L. Chung, W.L Yu and C.N. Lin, "A self-propagating high-temperature synthesis method for synthesis of AlN powder", J. Mater. Res. 14 (1999) 1928.

[9] H. Wang, J. Han, Z. Li and S. Du, "Effect of additives on self-propagating high-temperature synthesis of AlN", J. Eur. Ceram. Soc. 21 (2001) 2193.

[10] B.C. Di Lello, F.J. Moura and I.G. Solórzano, "Synthesis and characterization of nano-scale aluminum nitride produced from vapor phase", Mater. Sci. Eng. C 15 (2001) 67.

[11] M.C. Wang, M.S. Tsai and N.C. Wu, "Effect of heat treatment on phase transformation of aluminum nitride ultrafine powder prepared by chemical vapor deposition", J. Cryst. Growth 210 (2000) 487.

[12] T.G. Kim, Y.H. Shin, H. Cho and J.K. Kim, "Synthesis of transparent diamond-like carbon film on the glass by radio-frequency plasma enhanced chemical vapor deposition”, J. Korean Cryst. Growth Cryst. Technol. 22 (2012) 190.

[13] M. Yamada, T. Yasui, M. Fukumoto and K. Takahashi, "Nitridation of aluminum particles and formation process of aluminum nitride coatings by reactive RF plasma spraying", Thin Solid Films 515 (2007) 4166.

[14] S.M. Oh and D.W. Park, "Development of plasma process for preparing ultrafine aluminum nitride", J. Industr. Eng. Chem. 6 (2000) 1.

[15] N.S. Kanhe, A.B. Nawale, R.L. Gawade, V.G. Puranik,
S.V. Bhoraskar, A.K. Das and V.L. Mathe, "Understanding the growth of micro and nano-crystalline AlN by thermal plasma process", J. Cryst. Growth 339 (2012) 36.

[16] B.H. Li, H. Yang, G. Zou and S. Yu, "Ultrafine AIN and Al-AlN powders: preparation by DC arc plasma and thermal treatment", Advan. Mat. 9 (1991) 156.

[17] K. Etemadi, "Formation of aluminum nitrides in thermal plasmas", J. Plasma Chem. Plasma Process. 11 (1991) 41.

[18] H.D. Li, G.T. Zou, H. Wang, H.B. Yang, D.M. Li, M.H. $\mathrm{Li}$ and $\mathrm{S}$. Yu, "Synthesis and infrared study of nanosized aluminum nitride powders prepared by direct current arc plasma", J. Phys. Chem. B 102 (1998) 8692.

[19] N. Hashimoto, H. Yoden and S. Deki, "Effect of milling treatment on the particle size in the preparation of AIN powder from aluminum polynuclear complexes", J. Am. Ceram. Soc. 76 (1993) 438.

[20] P.C. Kong and Y.C. Lau, "Plasma synthesis of ceramic powders", Pure \& Appl. Chem. 62 (1990) 1809.

[21] D. vollate, "Plasma synthesis of nanoparticles", KONA Powder Particle 25 (2007) 39.

[22] R. Dolbec, M. Bolduc, X. Fan, J. Guo, J. Jurewicz, T. Labrot, S. Xue and M. Boulos, "Nanopowders synthesis at industrial-scale production using the inductively coupled plasma technology", NSTI Nanotech 2008 Proceedings 1 (2008) 672.

[23] FactSage, software program, version 6.2, CRCT-ThermFact Inc. \& GTT-Technologies, Canada \& Germany (2010).

[24] C. Mandilas, E. Daskalos and G. Karagiannakis, "Synthesis of aluminum nanoparticles by arc plasma spray under atmospheric pressure", J. Mater. Sci. Eng. B 178 (2013) 22.

[25] C. Papelis, W. Um, C.E. Russell and J.B. Chapman, "Measuring the specific surface area of natural and manmade glasses: effect of formation process, morphology, and particle size", Colloids Surf. A 215 (2003) 221.

[26] C.H. Li, L.H. Kao, M.J. Chen, Y.F. Wang and C.H. Tsai, "Rapid preparation of aluminum nitride powders by using microwave plasma", J. Allo. Comp. 542 (2012) 78 .

[27] M.L. Panchula and J.Y. Ying, "Nanocrystalline aluminum nitride: i, vapor-phase synthesis in a forced-flow reactor", J. Am. Ceram. Soc. 86 (2003) 1114. 